\title{
Penggunaan MS Excel untuk Estimasi Model GARCH(1,1)
}

\author{
Didit B. Nugroho ${ }^{1,2, *}$, Bambang Susanto ${ }^{1}$, Mince M. M. Rosely ${ }^{1}$ \\ ${ }^{1}$ Program Studi Matematika \\ ${ }^{2}$ Study Center for Multidisciplinary Applied Research and Technology (SeMARTy) \\ Universitas Kristen Satya Wacana \\ Jl. Diponegoro 52-60, Salatiga, Central Java 50711 Indonesia \\ *Corresponding author: didit.budinugroho@staff.uksw.edu
}

\begin{abstract}
Abstrak
Permasalahan umum yang sering dijumpai dalam banyak studi keuangan yaitu volatilitas tak konstan untuk return aset. Suatu pendekatan untuk memodelkan runtun waktu keuangan dengan heteroskedastisitas pada return aset yaitu model GARCH. Studi ini bertujuan untuk menunjukkan bagaimana MS Excel dapat digunakan untuk mengestimasi model GARCH(1,1). MS Excel menawarkan suatu kemudahan penghitungan dan mungkin merupakan piranti yang paling banyak digunakan untuk menganalisis data keuangan. Untuk tujuan penyelidikan, studi ini mengadopsi data simulasi dan data riil kurs beli USD terhadap IDR periode 2010-2017. Parameter-parameter dalam model GARCH(1,1) diestimasi menggunakan metode likelihood maksimum dengan bantuan Solver yang tersedia di MS Excel. Hasil empiris pada data simulasi menunjukkan bahwa MS Excel menyediakan keakuratan yang baik untuk menaksir model GARCH(1,1). Aplikasi untuk data riil menghasilkan nilai-nilai optimal untuk model $\operatorname{GARCH}(1,1)$ yang serupa dengan yang dihasilkan oleh metode-metode MCMC menggunakan alat bantu Matlab.

Kata kunci: Excel, GARCH(1,1), kurs beli, volatilitas
\end{abstract}

\begin{abstract}
A common problem often encountered in many financial studies is nonconstant volatility of asset returns. An approach to modeling financial time series with heteroscedasticity in returns is GARCH model. This study aims to show how MS Excel can be used to estimate the GARCH(1,1) model. That software offers a user-friendly tool to calculation and is probably the most widely used software to perform financial analysis. For investigation purpose, simulated data and actual USD/IDR exchange rate over the period 20002017 were considered. An iterative function called Solver was used to determine the maximum likelihood estimates for the GARCH parameters. Empirical results based on simulation data show that MS Excel provides a good estimation accuracy for the GARCH(1,1) model. An application to real data yields optimal values for the GARCH(1,1) model similar to those estimated by $M C M C$ methods using Matlab software.

Keywords: Excel, GARCH(1,1), buying rate, volatility
\end{abstract}

2000 Mathematics Subject Classification: Primary 60G10, Secondary 62M10, 90C31, 91B84. Received: 2018-07-06, accepted: 2018-10-30. 


\section{Pendahuluan}

Volatilitas (volatility) merupakan salah satu dari indikator-indikator risiko paling penting bagi pelaku dan pengamat pasar keuangan. Dalam manajemen risiko, volatilitas seringkali digunakan sebagai suatu istilah umum untuk variansi atau simpangan baku (Christoffersen, [8]). Menurut Poon \& Granger [29], suatu pendekatan yang telah digunakan secara luas untuk pemodelan dan peramalan volatilitas aset keuangan yaitu model GARCH (generalized autoregressive conditional heteroscedasticity) yang diperkenalkan oleh (Bollerslev, [5]). Secara khusus, model GARCH yang paling banyak diaplikasikan dalam studi keuangan yaitu model $\operatorname{GARCH}(1,1)$ (lihat [16, 30, 33] untuk alasan detilnya).

Beberapa metode yang dapat digunakan untuk mengestimasi parameter-parameter pada model GARCH antara lain maximum likelihood (ML) method (Fan et al., [10]; Francq \& Za-

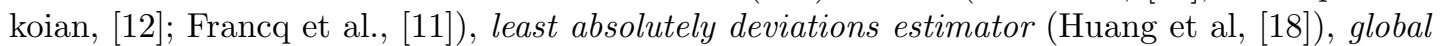
and local optimization methods (Adanu, [Z] ), dan metode Markov chain Monte Carlo (Nugroho \& Susanto, [27]; Nugroho et al., [28]; Salim et al., [34]). Lebih lanjut, metode-metode estimasi tersebut dapat diimplementasikan pada perangkat lunak komputasi matematika seperti Matlab, WinBUGS, R, Stata, Phyton, SAS, dan OxMetrics. Sayangnya, meskipun perangkat lunak tersebut telah menyediakan fungsi tertentu untuk pengestimasian model GARCH, ini hanya dikenal oleh pengguna-pengguna tertentu, misalnya matematikawan, statistikawan, dan insinyur.

Suatu alternatif yang menarik bagi akademisi dan praktisi yaitu lembar kerja MS Excel. Ini merupakan lembar kerja (spreadsheet) yang paling umum digunakan dan telah berkembang menjadi perangkat canggih yang dapat digunakan oleh banyak cabang ilmu pengetahuan dan teknik. Sebagai contoh, studi penggunaan lembar kerja MS Excel yang diarahkan bagi akademisi dan praktisi keuangan telah dilakukan oleh Brewer et al. [6], Brown \& Klingenberg [], French [13], 14], Giot \& Laurent [15], Kyng [21], Kyng \& Konstandatos [22], Nadler \& Kros [25], dan Williams [37]. Dalam komunitas keuangan, MS Excel digunakan secara luas karena ada banyak situasi dimana optimisasi numerik perlu dilakukan pada data yang terkandung dalam MS Excel.

Khusus dalam konteks GARCH model, terdapat beberapa literatur tentang tentang penggunaan Excel yang ditujukan bagi akademisi dan praktisi, sebagai contoh, lihat Alexander [4], Christoffersen [8], Levy [24], Racicot \& Theoret [3I], Rouah \& Vainberg [32], dan Tung et al. [36]. Meskipun literatur-literatur tersebut telah memberikan contoh implementasi Excel baik menggunakan Visual Basic for Applications (VBA) ataupun tidak, tetapi tidak mendemonstrasikan langkah-langkahnya secara jelas, kecuali Tung et al. [36]. Meskipun begitu, Tung et al. [36] tidak mendemonstrasikannya untuk data simulasi, analisis keakuratan estimasi, dan deskripsi data.

Bagi praktisi keuangan dan akademisi di area ekonometrika/matematika keuangan yang tidak mempunyai pengetahuan yang cukup dalam pemrograman komputer (sebagai contoh, ekonomi, matematika, dan statistik), Excel Solver menawarkan suatu alternatif yang mudah dan nyaman dibandingkan dengan program-program komersial yang mahal seperti Matlab, Maple, dan Mathematica. Lebih lanjut, bagi yang tidak mempunyai pengetahuan yang cukup tentang metode statistik atau matematika untuk mengestimasi model-model volatilitas seperti GARCH, lembar kerja Excel menyediakan suatu strategi untuk mengestimasi model volatilitas dan membolehkan eksperimen yang lebih lanjut untuk model yang lebih rumit. Karena itu, tujuan utama dari studi ini yaitu melaporkan suatu strategi pembelajaran metode statistik, ukuran statistik, dan metode numerik untuk ekonometrika keuangan dengan menunjukkan bagaimana lembar kerja MS Excel (tanpa menggunakan VB) dapat digunakan untuk mengestimasi model $\operatorname{GARCH}(1,1)$. Studi ini mendemonstrasikan langkah-langkah penggunaan MS Excel untuk mengestimasi model $\operatorname{GARCH}(1,1)$ yang diaplikasikan pada data simulasi dan data riil kurs beli USD terhadap IDR periode 2010-2017. Data diunduh dari laman Bank Indonesia (http://www.bi.go.id). Sejauh pengetahuan penulis, belum ada literatur yang menyelidiki penggunaan MS Excel untuk model GARCH pada data simulasi beserta keakuratannya secara 
numerik dan juga penghitungan ukuran-ukuran statistik terhadap data. Lebih lanjut, hasil estimasi dari Solver Excel divalidasi dengan hasil estimasi menggunakan metode Markov Chain Monte Carlo (MCMC) yang diimplementasikan dalam program Matlab yang dibuat sendiri oleh penulis.

Artikel ini disusun seperti berikut: Bagian 2 menyajikan metode penelitian, Bagian 3 membahas pengestimasian model GARCH menggunakan MS Excel, dan Bagian 4 memberikan kesimpulan dan rekomendasi.

\section{Metode Penelitian}

Studi ini membangun suatu lembar kerja sederhana di MS Excel 2016 untuk memperkenalkan analisis model GARCH pada suatu lingkungan yang mudah dipahami. Karena itu langkah-langkah penelitian tidak memerlukan pengetahuan pemrograman tetapi membuat lembar kerja MS Excel yang mudah dipahami oleh akademisi dan praktisi keuangan. Sebagai contoh, studi ini memperhatikan model $\operatorname{GARCH}(1,1)$ dan mengadopsi data simulasi dan data riil kurs beli USD terhadap IDR periode 2010-2017.

2.1. Model GARCH $(\mathbf{1}, \mathbf{1})$ dan Estimasinya. Bagian ini membahas secara singkat tentang suatu model volatilitas yang dikenal sebagai model $\operatorname{GARCH}(1,1)$, yang diusulkan oleh Bollerslev (1986). Ciri khas dari model tersebut yaitu bahwa volatilitas untuk return harga aset tidak konstan. Mengikuti proses stokastik, return $R_{t}$ dapat dibangkitkan melalui sampel-sampel normal acak seperti berikut:

$$
R_{t}=\sigma_{t} e_{t}, \quad e_{t} \sim N(0,1)
$$

Dalam $\operatorname{GARCH}(1,1)$, variansi (volatilitas kuadrat) saat ini, $\sigma_{t}^{2}$, dihitung berdasarkan return kuadrat berbobot periode sebelumnya $R_{t-1}^{2}$ dan variansi berbobot periode sebelumnya $\sigma_{t-1}^{2}$. Persamaan untuk GARCH $(1,1)$ yaitu

$$
\sigma_{t}^{2}=\omega+\alpha R_{t-1}^{2}+\beta \sigma_{t}^{2},
$$

yang mana faktor-faktor bobot memenuhi syarat $\omega, \alpha, \beta>0$ dan $\alpha+\beta<1$.

Berdasarkan asumsi normal acak di persamaan (四), likelihood untuk data pengamatan bersyarat parameter dinyatakan sebagai berikut:

$$
L\left(R_{1}, R_{2}, \ldots, R_{T} \mid \omega, \alpha, \beta\right)=\prod_{t=1}^{T} \frac{1}{\sqrt{2 \pi \sigma_{t}^{2}}} \exp \left\{-\frac{R_{t}^{2}}{2 \sigma_{t}^{2}}\right\} .
$$

Parameter-parameter optimal untuk model membangkitkan volatilitas $\left\{\sigma_{1}, \sigma_{2}, \ldots, \sigma_{T}\right\}$ yang memaksimumkan likelihood $L$ atau ekivalen dengan logaritma likelihood yang diberikan oleh

$$
\ln (L)=-\frac{1}{2} \sum_{t=1}^{T}\left[\ln \left(2 \pi \sigma_{t}^{2}\right)-\frac{R_{t}^{2}}{2 \sigma_{t}^{2}}\right] .
$$

2.2. Cakupan Studi dan Variabel. Tujuan utama dari studi ini yaitu menyajikan langkahlangkah pengestimasian model $\mathrm{GARCH}(1,1)$ dan analisisnya dalam lembar kerja MS Excel tanpa VB. Studi menggunakan data runtun waktu yang dibangkitkan dari model untuk mengetahui keakuratan penghitungan MS Excel dan data riil runtun waktu keuangan. Model hanya menguji satu variabel, kurs beli harian USD terhadap IDR periode 2010-2017, tidak termasuk akhir pekan dan hari libur nasional, yang terdiri dari 1964 pengamatan. Data kurs beli diunduh dari laman Bank Indonesia, dan selanjutnya dikonversi ke return (dalam persen) menggunakan rumus

$$
R_{t}=100 \times \ln \frac{P_{t}}{P_{t-1}}
$$

yang mana $P_{t}$ adalah kurs beli mata uang asing terhadap IDR pada hari ke-t. Rumus di atas dikenal sebagai log-returns dan umum digunakan dalam aplikasi seperti di Abdalla \& Winker [I], Alberg et al. [3], Epaphra [9], dan Kamal et al. [IT]. 
2.3. Penggunaan Solver dalam Pengestimasian Model GARCH(1,1). Studi ini menyajikan pembangkitan data runtun waktu keuangan berdasarkan model $\operatorname{GARCH}(1,1)$, penghitungan statistik deskriptif, serta implementasi masalah optimasi dan penyelesaiannya menggunakan MS Excel. Kalkulasi dilakukan dengan menggunakan rumus dalam sel lembar kerja. Secara khusus, masalah optimasi diselesaikan dengan bantuan Solver, yang meniadakan kemampuan pemrograman. Solver dirancang untuk menemukan penyelesaian optimal dari satu atau banyak persamaan, bahkan jika persamaan tersebut tidak linier. Solver tidak terpasang secara otomatis. Petunjuk pemasangan dapat dipelajari di http://office.microsoft.com/en-us/ excel-help/introduct. Panduan komprehensif tentang Solver dapat dilihat di Harmon [I7]. Keuntungan penggunaan fungsi Solver antara lain yaitu dapat menggantikan metode trial-anderror dan menghemat waktu untuk memecahkan masalah yang sama atau serupa karena dapat digunakan berulang kali dengan data input, kendala, perubahan sel (variabel), dan sel target (parameter) yang berbeda (Kuka \& Karamani, [20]).

\section{IMPLEMENTASI MS EXCEL}

Pada bagian ini, model GARCH(1,1) diimplementasikan pada MS Excel dengan langkahlangkah yang jelas berdasarkan pada data simulasi dan data riil.

3.1. Data Simulasi. Gambar $\mathbb{m}$ mengilustrasikan bagaimana data return runtun waktu yang terdiri dari 1000 pengamatan dapat dibangkitkan dan dicocokkan berdasarkan model $\operatorname{GARCH}(1,1)$ dalam suatu lembar kerja MS Excel. Langkah-langkah untuk membangkitkan data simulasi dan mengestimasi model GARCH menggunakan Solver adalah seperti berikut ini.

L1. Memasukkan nilai sebenarnya untuk parameter-parameter dari volatilitas (区]), sebagai contoh $\omega=0,05, \alpha=0,1$, dan $\beta=0,85$, berturut-turut pada sel B5, B6, dan B7. Nilai $\alpha+\beta$ dihitung pada sel B8.

L2. Membangkitkan barisan 1000 data return error $\left(e_{1}, e_{2}, \ldots, e_{T}\right)$ yang berdistribusi $N(0,1)$ dalam rentang sel B13:B1012, yaitu sel B13=NORMSINV $(\operatorname{RAND}())$ dan rumus disalin sampai sel B1012.

L3. Menetapkan nilai $\sigma_{1}^{2}=e_{1}^{2}$ dan $R_{1}=\sigma_{1}$ berturut-turut pada sel $\mathrm{C} 13=\mathrm{B} 13^{\wedge} 2$ dan $\mathrm{D} 15=\mathrm{SQRT}(\mathrm{C} 13)$.

L4. Menghitung barisan variansi $\left(\sigma_{2}^{2}, \sigma_{3}^{2}, \ldots, \sigma_{T}^{2}\right)$ pada rentang sel C14:C1012 sesuai rumus (Z2) dan barisan return $\left(R_{2}, R_{3}, \ldots, R_{T}\right)$ pada rentang sel D14:D1012 sesuai rumus

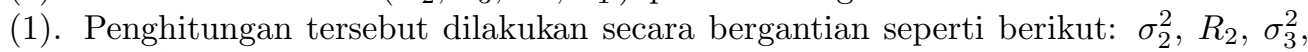
$R_{3}, \ldots, \sigma_{T}^{2}, R_{T}$, dengan menyalin rumus C14:D14 secara simultan untuk C15:D15 sampai C1012:D1012.

L5. Mengestimasi variansi $\left(\sigma_{2}^{2}, \sigma_{3}^{2}, \ldots, \sigma_{T}^{2}\right)$ pada rentang sel E13:E1012 berdasarkan nilai estimasi parameter $(\omega, \alpha, \beta)$ di sel D5:D7. Secara khusus, ditetapkan estimasi $\sigma_{1}^{*}=\sigma_{1}$ di sel E13=C13. Dicatat bahwa estimasi awal untuk $(\omega, \alpha, \beta)$ yaitu $\omega_{0}=0,01, \alpha_{0}=$ 0, 08, dan $\beta_{0}=0,90$ dalam sel C5:C7 dan D5:D7.

L6. Menghitung log-likelihood (I) di rentang sel F13:F1012 berdasarkan nilai estimasi variansi E13:E1012 di Langkah 5: F13=-0,5*(LN $\left.\left(2^{*} \mathrm{PI}()^{*} \mathrm{E} 13\right)+\mathrm{D} 13^{\wedge} 2 / \mathrm{E} 13\right)$ dan selanjutnya rumus disalin sampai F1012.

Karena studi ini tertarik untuk menentukan $(\omega, \alpha, \beta)$ yang memaksimumkan $\ln (L)$, maka ini bisa dicapai dengan menggunakan algoritma Solver yang tersedia di MS Excel seperti berikut ini.

L7. Klik menu "Data" dan klik "Solver", maka jendela "Solver Parameters" muncul seperti Gambar 『. Pada jendela tersebut, hasil yang diinginkan untuk ditetapkan sebagai target cell yaitu D9, yang merupakan nilai total log-likelihood, centang "Equal To" sebagai "Max" untuk memaksimumkan. Sel D5:D7 dimasukkan sebagai sel variabel dalam "By Changing Cells" untuk nilai-nilai estimasi $(\omega, \alpha, \beta)$ dan centang "Make Unconstrained Variables Non-Negative". Untuk metode penyelesaian, studi ini memilih metode "GRG Nonlinear". 
L8. Klik "Options" untuk membuka jendela "Solver Options". Dalam studi ini Solver Options diisi seperti pada Gambar 3. Selanjutnya klik "OK" dan klik "Solve", maka Solver akan menghasilkan nilai-nilai parameter yang optimal di sel D5:D7 yaitu $\omega=$ 0,0376, $\alpha=0,0895$, dan $\beta=0,8758$ yang sebelumnya diisi dengan nilai-nilai awal untuk parameter. Nilai log-likelihood maksimum yang berkorespondensi yaitu $-1408,1$ yang lebih besar dari log-likelihood awal senilai $-1417,8$.

\begin{tabular}{|c|c|c|c|c|c|c|c|}
\hline 4 & A & $B$ & C & $\mathrm{D}$ & $E$ & $\mathrm{~F}$ & G \\
\hline 1 & \multirow{2}{*}{\multicolumn{7}{|c|}{ GARCH $(1,1)$ pada Data Simulasi }} \\
\hline 2 & & & & & & & \\
\hline 3 & \multicolumn{5}{|c|}{ Nilai parameter } & & \\
\hline 4 & & Sebenarnya & Awal & Estimasi & Galat relatif & & \\
\hline 5 & omega $=$ & 0,0500 & 0,0100 & 0,0376 & $25 \%$ & & \\
\hline 6 & alpha $=$ & 0,1000 & 0,0800 & 0,0895 & $10 \%$ & & \\
\hline 7 & beta $=$ & 0,8500 & 0,9000 & 0,8758 & $3 \%$ & & \\
\hline 8 & alpha+beta $=$ & 0,9500 & 0,9800 & 0,9654 & $2 \%$ & & \\
\hline 9 & Total $\operatorname{Ln}(L)=$ & & $-1417,8$ & $-1408,1$ & & & \\
\hline \multicolumn{8}{|l|}{10} \\
\hline 11 & hari & returns error & var sebenarnya & returns sebenarnya & var estimasi & log likelihood & returns mutlak \\
\hline 12 & $t$ & varepsilon_t & sigma_t^2 & $R \_t$ & sigma* $t^{\wedge} 2$ & $\operatorname{Ln}\left(L \_t\right)$ & $\left|R \_t\right|$ \\
\hline 13 & 1 & 1,022392962 & 1,045287368 & 1,022392962 & 1,045287368 & $-1,441084454$ & 1,022392962 \\
\hline 14 & 2 & 1,474498829 & 1,043023 & 1,5058835 & 1,046702577 & $-2,025012845$ & 1,5058835 \\
\hline 15 & 3 & $-0,150680366$ & 1,163338061 & $-0,162521056$ & 1,157401053 & $-1,003437562$ & 0,162521056 \\
\hline 16 & 4 & 1,200426346 & 1,041478661 & 1,22506944 & 1,053659561 & $-1,657255417$ & 1,22506944 \\
\hline 17 & 5 & $-1,741269484$ & 1,085336376 & $-1,814045469$ & 1,094823343 & $-2,46710808$ & 1,814045469 \\
\hline 18 & 6 & $-0,691772133$ & 1,301612016 & $-0,789230459$ & 1,291157081 & $-1,28791975$ & 0,789230459 \\
\hline 19 & 7 & $-1,568290194$ & 1,218658685 & $-1,731280634$ & 1,224216729 & $-2,244272974$ & 1,731280634 \\
\hline 20 & 8 & 0,222710276 & 1,385593146 & 0,262154984 & 1,3782077 & $-1,104263306$ & 0,262154984 \\
\hline 21 & 9 & 0,59680571 & 1,234626697 & 0,663133246 & 1,250835598 & $-1,206625212$ & 0,663133246 \\
\hline 22 & 10 & 0,261516396 & 1,143407263 & 0,279640065 & 1,172503214 & $-1,031855859$ & 0,279640065 \\
\hline
\end{tabular}

GAmBAR 1. Implementasi MS Excel untuk GARCH(1,1) mengadopsi data simulasi.

Gambar ⿴囗 menyajikan returns mutlak yang dihasilkan dari pembangkitan dan juga variansi yang dihasilkan berdasarkan nilai-nilai estimasi parameter. Gambar tersebut menunjukkan bahwa ketiga runtun waktu tersebut menunjukkan pola yang sama. Hal ini mengindikasikan bahwa hasil-hasil penghitungan sudah sesuai seperti rumus yang diberikan.

Seberapa baik Solver mengestimasi model GARCH(1,1)? Untuk menjawab pertanyaan ini, berdasarkan kasus data simulasi, nilai estimasi optimal dibandingkan dengan nilai sebenarnya untuk parameter-parameter model. Galat relatif untuk estimasi $\omega, \alpha$, dan $\beta$ berturutturut yaitu 10\%, 8\%, dan 1\%, yang mengindikasikan bahwa Solver mampu untuk memberikan hasil estimasi yang akurat. Sementara itu, menggunakan metode Adaptive Random Walk Metropolis (ARWM) dalam algoritma MCMC (lihat Nugroho [26] ) yang diimplementasikan sendiri oleh penulis ke program Matlab, hasil estimasi parameternya yaitu $\omega=0,0497$ dengan galat relatif $0,6 \%, \alpha=0,1026$ dengan galat relatif $2,6 \%$, dan $\beta=0,8530$ dengan galat relatif $0,35 \%$ ). Hal ini mengindikasikan bahwa metode ARWM mampu mengestimasi parameter dengan lebih akurat. Meskipun begitu, penulis mencatat bahwa estimasi dari Solver Excel memberikan loglikelihood $\operatorname{Ln}(L)=-1408,1$ yang lebih besar daripada yang dihasilkan metode ARWM sebesar $\operatorname{Ln}(L)=-1409,83$. Hasil tersebut mengindikasikan bahwa Solver Excel Solver memberikan estimasi parameter yang lebih mengoptimakanl log-likelihood daripada metode ARWM.

3.2. Data Riil. Bagian ini mengaplikasikan model $\operatorname{GARCH}(1,1)$ untuk data kurs beli USD terhadap IDR periode Januari 2010 sampai Desember 2017 yang terdiri dari 1964 pengamatan. Data nilai kurs disajikan dalam rentang sel C13:C1976 dan returns (7) dihitung dalam rentang sel D14:D1976. Sebagai contoh, rumus D14=100*(LN(C14)-LN(C13)). Gambar 1 menyajikan plot runtun waktu returns kurs beli USD terhadap IDR yang berfluktuasi di sekitar nol dan memperlihatkan stasioneritas dari returns.

3.2.1. Deskripsi Data. Analisis awal terhadap data return menggunakan statistik deskriptif diperlukan untuk mengetahui karakteristik data. Tabel m menyajikan ringkasan statistik deskriptif untuk data returns. Rerata, simpangan baku, kurtosis, dan skewness dihitung pada sel I6 
76 Nugroho et al., JMI Vol 14 No 2 Okt 2018, pp. 71-82,doi:10.24198/jmi.v14.n2.2018.71-82

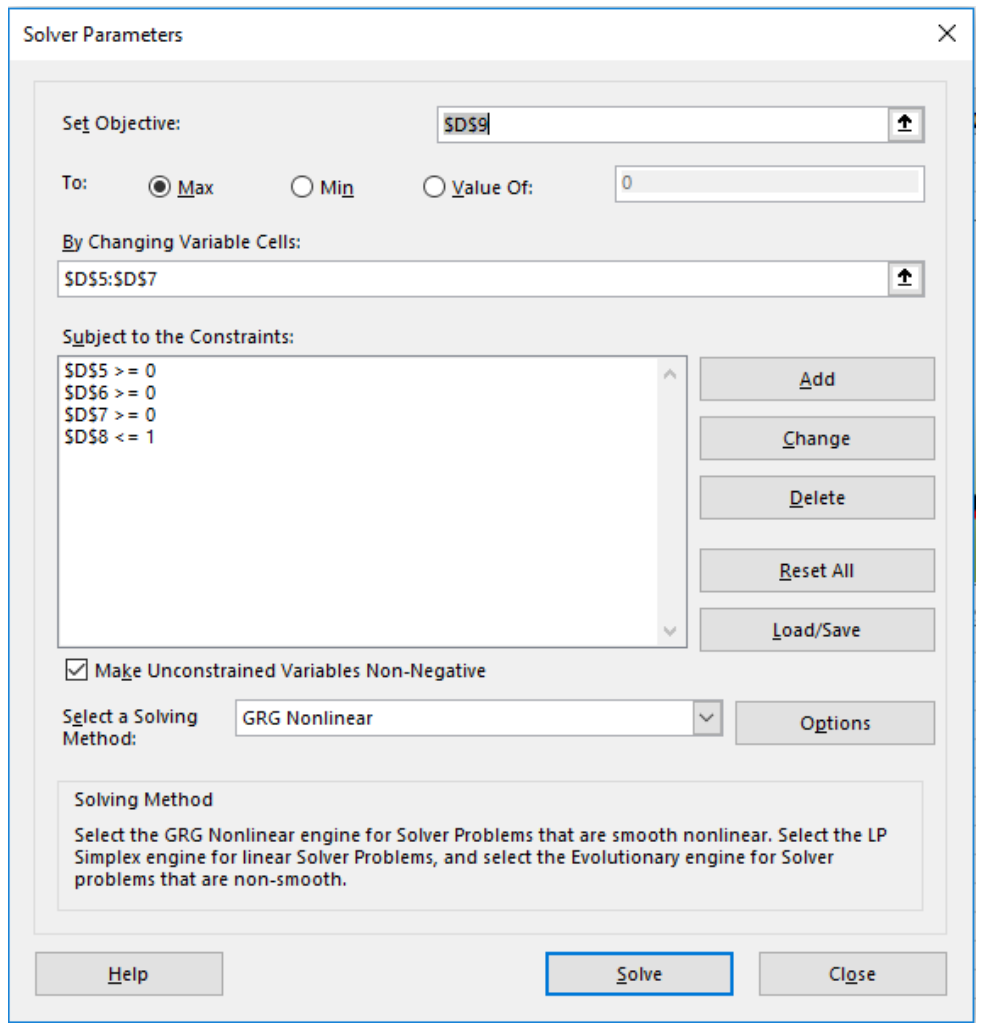

GAmBAR 2. Jendela "Solver Parameters".

\begin{tabular}{|c|c|}
\hline Options & $?$ \\
\hline All Methods GRG Nonlinear Evolutionary & \\
\hline Constraint Precision: & 0,000001 \\
\hline$\square \underline{\text { Unse Automatic Scaling }}$ & \\
\hline$\square$ show Iteration Results & \\
\hline Solving with Integer Constraints & \\
\hline$\square$ Ignore Integer Constraints & \\
\hline Integer Optimality (\%): & 500 \\
\hline Solving Limits & \\
\hline Max Iime (Seconds): & 100 \\
\hline Iterations: & 100 \\
\hline Evolutionary and Integer Constraints: & \\
\hline Max Subproblems: & \\
\hline Max Feasible Solutions: & \\
\hline$\underline{\mathrm{O} K}$ & Çancel \\
\hline
\end{tabular}

Gambar 3. Jendela "Solver Options". 


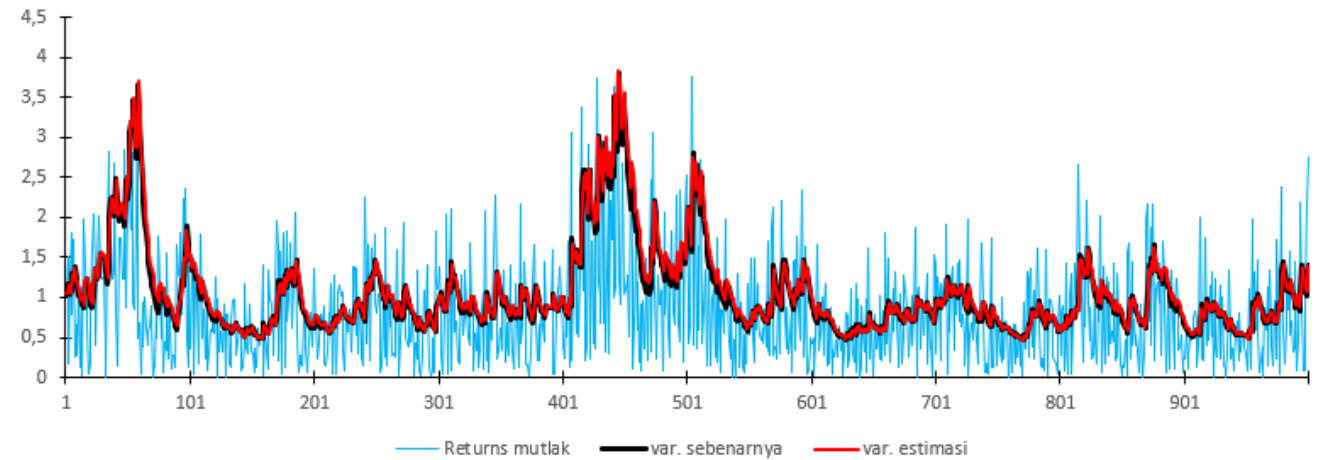

GAmBAR 4. Plot harian untuk returns mutlak, variansi hasil pembangkitan, dan variansi hasil estimasi.

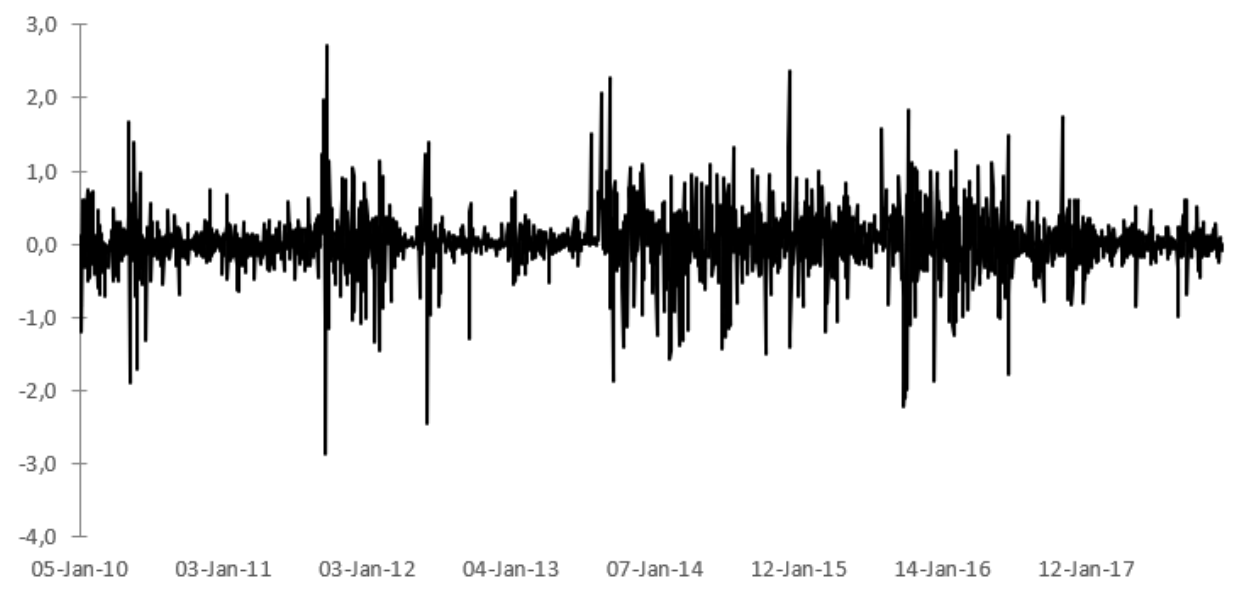

GAMBAR 5. Plot runtun waktu returns kurs beli USD terhadap IDR periode 2010-2017.

TABEL 1. Statistik deskriptif data returns kurs beli USD terhadap IDR tahun 2010-2017.

\begin{tabular}{cccccc}
\hline Rerata & Simpangan Baku & Kurtosis & Skewness & Stat-JB & Stat-LB \\
\hline 0,0190 & 0,4297 & 6,53 & $-0,35$ & 1061,7 & 9,27 \\
\hline
\end{tabular}

sampai I9 berturut-turut menggunakan fungsi AVERAGE, STDEV, KURT, dan SKEW. Dalam studi ini normalitas dan autokorelasi data diuji berturut-turut menggunakan Uji Jarque-Bera (JB test) dan Uji Ljung-Box (LB test).

Uji JB untuk normalitas returns didasarkan pada koefisien kurtosis dan skewness. Rumus statistik JB (Thadewald \& Bning, [35]):

$$
J B=\frac{T}{6}\left(\text { skewness }^{2}+\frac{(\text { kurtosis }-3)^{2}}{4}\right) .
$$

diketikkan pada sel $\mathrm{K} 5=\mathrm{I} 5 / 6^{*}(\mathrm{I} 9 \wedge 2+(\mathrm{I} 8-3) \wedge 2 / 4), \mathrm{K} 6=\mathrm{CHIINV}(0,05 ; 2)$ untuk nilai $\chi^{2}$ dengan derajat kebebasan $2, \mathrm{~K} 7=\mathrm{CHIDIST}(\mathrm{K} 5 ; 2)$ untuk menghitung p-value, dan K8=IF(K7;0,05; "Tidak Normal"; "Normal") untuk menentukan normalitas data. Dengan tingkat signifikansi 0,05, Uji JB menolak normalitas data returns kurs beli USD karena statistik JB lebih besar dari nilai $\chi^{2}$, i.e, 1061, $7>5,99$ (atau $0<0,05$ ). Hasil tersebut banyak dijumpai dalam banyak kasus data keuangan yang mana returns aset keuangan tidak berdistribusi normal. Meskipun begitu, 
studi ini tetap mengasumsikan distribusi normal untuk returns sebagai suatu kerangka untuk studi lebih lanjut menggunakan distribusi lain.

Uji LB sampai lag 10 diaplikasikan pada data returns untuk menguji autokorelasi. Persamaan untuk statistik LB (Lawrence et al., [23]) sampai lag- $h$ :

$$
L B=T(T+2) \sum_{k=1}^{h}(T-k) r_{k}^{2},
$$

yang mana $r_{k}$ adalah koefisien autokorelasi dari lag- $k$ dan $h$ adalah banyaknya koefisien autokorelasi yang akan diuji. Rentang sel H15:H24 memasukkan banyaknya lag dari 1 sampai 10. Koefisien autokorelasi $r_{k}$ dihitung pada sel I15=SUMPRODUCT(OFFSET(D \$14:D \$1976;0;0; $\$ 5$ H15;1)-I \$6;OFFSET(D \$14:D \$1976;H15;0;I \$5-H15;1)-I\$6)/DEVSQ(D \$14:D \$1976) yang selanjutnya disalin sampai sel I24. Rentang sel J15:J24 menghitung $r_{k}^{2}$ yang digunakan untuk menghitung statistik LB di sel M $5=\mathrm{I} \$ 5 *(\mathrm{I} \$ 5+2) * \mathrm{SUM}(\mathrm{J} 15: \mathrm{J} 24)$. Sementara itu, $\chi^{2}$ di sel M6 $=\operatorname{CHIINV}(0,05 ; 10)$ dan p-value di sel M7 $=\operatorname{CHIDIST}(\mathrm{M} \$ 5 ; 10)$. Keputusan autokorelasi ada di sel M8=IF(M7 0,$05 ;$;Tidak"; "Berautokorelasi"). Pada studi kasus ini diperoleh bahwa returns kurs beli USD tidak berutokorelasi karena statistik LB lebih kecil dari nilai $\chi^{2}$. Hal ini sesuai dengan asumsi model bahwa returns tidak berautokorelasi.

3.2.2. Estimasi Model. Nilai-nilai parameter model GARCH(1,1) untuk returns kurs beli USD terhadap IDR periode 2010-2017 dicari dengan nilai-nilai awal yaitu $\omega=0,0001, \alpha=0,05$, dan $\beta=0,90$ berturut-turut di sel C4, C5, dan C6. Pencarian menggunakan Solver mengikuti Langkah 5 sampai Langkah 8 seperti pada data simulasi. Variansi GARCH, $\sigma_{t}^{2}$, dihitung pada rentang sel E14:E1976, yang mana variansi awalnya yaitu E14=D14 $\wedge$ 2. Sementara itu, log-likelihood dihitung pada rentang sel F14:F1976. Solver memberikan penyelesaian optimal $\omega=0,0055, \alpha=0,2035$, dan $\beta=0,7924$ dengan log-likelihood $\operatorname{Ln}(L)=762,31$. Gambar G mengilustrasikan bagaimana penghitungan di atas disusun dalam lembar kerja MS Excel. Perbandingan penyelesaian tersebut dengan metode MCMC (lihat Nugroho [26] ) seperti ARWM dan Independence Chain Metropolis-Hastings (IC-MH) disajikan dalam Tabel [2. Perbandingan plot untuk runtun waktu variansi berdasarkan nilai-nilai estimasi parameter yang diperoleh menggunakan metode ML dan ARW disajikan pada Gambar $\mathbb{0}$. Terlihat bahwa penyelesaian optimal menggunakan metode ML yang dihasilkan oleh Solver serupa dengan yang dihasilkan oleh metode lain menggunakan alat bantu Matlab. Ini menegaskan hasil pada data simulasi bahwa Solver mempunyai kemampuan untuk mengestimasi model $\operatorname{GARCH}(1,1)$ secara akurat. Berbeda dengan hasil pada data simulasi, dalam kasus ini metode MCMC memberikan estimasi paramater yang lebih memaksimumkan log-likelihood.

TABEL 2. Perbandingan penyelesaian $\operatorname{GARCH}(1,1)$.

\begin{tabular}{cccccc}
\hline Metode & Alat Bantu & $\omega$ & $\alpha$ & $\beta$ & $\operatorname{Ln}(L)$ \\
\hline ML & Excel & 0,0055 & 0,2035 & 0,7924 & $-762,31$ \\
ARW & Matlab & 0,0060 & 0,1992 & 0,7879 & $-758,85$ \\
IC-MH & Matlab & 0,0057 & 0,1978 & 0,7915 & $-758,12$ \\
\hline
\end{tabular}

\section{Simpulan}

Studi ini mengaplikasikan Solver di MS Excel untuk menyelesaikan model GARCH $(1,1)$ berdistribusi normal yang mengadopsi data simulasi dan riil. Langkah-langkah penyelesaian disajikan dalam lembar kerja yang sederhana. Hasil berdasarkan data simulasi dan riil menunjukkan bahwa Solver mampu memberikan penyelesaian optimal yang akurat. Oleh karena itu, studi ini menyarankan penggunaan Solver bagi akademisi dan praktisi ekonometrika keuangan yang tidak memiliki pengetahuan yang cukup tentang pemrograman. Studi selanjutnya dapat menguji kemampuan Solver untuk mengestimasi model $\operatorname{GARCH}(1,1)$ dengan returns berdistribusi tak normal atau model varian dari GARCH. 


\begin{tabular}{|c|c|c|c|c|c|c|c|c|c|c|c|c|}
\hline 4 & A & B & $\mathrm{c}$ & D & E & $\mathrm{F}$ & $\mathrm{H}$ & I & J & $\mathrm{k}$ & L & M \\
\hline \multirow{2}{*}{\multicolumn{13}{|c|}{1 Estimasi GARCH(1,1) untuk data kurs beli USD terhadap IDR 2010-2017 }} \\
\hline \multicolumn{12}{|l|}{2} & \\
\hline 3 & Parameter & Nilai Awal & Estimasi & & & & Statistik deskri & iptif & & & & \\
\hline 4 & omega $=$ & 0,0001 & 0,00552468 & & & & Data Returns & \multicolumn{3}{|c|}{ D\$14 :D\$1976 Uji JB untuk normalitas: } & \multirow{2}{*}{\multicolumn{2}{|c|}{$\begin{array}{l}\text { Uji LB untuk autokorelasi: } \\
\qquad \text { Stat-JB }=9,266247374\end{array}$}} \\
\hline 5 & alpha $=$ & 0,0500 & 0,20347481 & & & & Banyak data $=$ & 1963 & Stat $-\mathrm{JB}=$ & 1061,70 & & \\
\hline 6 & beta $=$ & 0,9000 & 0,79244134 & & & & Rerata $=$ & 0,0190 & $\operatorname{Chi}^{\wedge} 2=$ & 5,9915 & $\operatorname{Chi}^{\wedge} 2=1$ & $=18,30703805$ \\
\hline 7 : & alpha+beta $=$ & 0,9500 & 0,99591615 & & & & Simp. Baku $=$ & 0,4297 & $p$-value $=$ & 0,0000 & $p-$ Value $=0$ & $=0,507036004$ \\
\hline 8[ & Total $\operatorname{Ln}(L)=$ & & $-762,3134$ & & & & Kurtosis $=$ & 6,5334 & Normalitas $=$ & Tidak Normal & Autokorelasi $=1$ & $=$ Tidak \\
\hline 9 & & & & & & & Skewness $=$ & $-0,3519$ & & & & \\
\hline 10 & & & & & & & & & & & & \\
\hline 11 & Hari & Tanggal & Kurs Beli & Returns & Vol. GARCH & Log-likelihood & Lag & Autokorelasi & & & & \\
\hline 12 & $t$ & & $P_{-} t$ & $R_{-} t$ & $\operatorname{sigma}^{\wedge} 2_{-} t$ & $\operatorname{Ln}\left(L_{-} t\right)$ & $k$ & $r_{-} k$ & $r^{\wedge} z_{-} k /(T-k)$ & & & \\
\hline 13 & 0 & 04-Jan-10 & 9283 & & & & & & & & & \\
\hline 14 & 1 & 05-Jan-10 & 9261 & $-0,2373$ & 0,0563 & 0,0196 & & & & & & \\
\hline 15 & 2 & 06-Jan-10 & 9261 & 0,0000 & 0,0616 & 0,4747 & 1 & $-0,018395508$ & $1,72474 \mathrm{E}-07$ & & & \\
\hline 16 & 3 & 07-Jan-10 & 9182 & $-0,8567$ & 0,0543 & $-6,2165$ & 2 & $-0,008417534$ & $3,6132 \mathrm{E}-08$ & & & \\
\hline 17 & 4 & 08-Jan-10 & 9194 & 0,1306 & 0,1979 & $-0,1521$ & 3 & $-0,017117164$ & $1,49488 \mathrm{E}-07$ & & & \\
\hline 18 & 5 & 11-Jan-10 & 9084 & $-1,2036$ & 0,1658 & $-4,3887$ & 4 & 0,05340347 & $1,45581 \mathrm{E}-06$ & & & \\
\hline 19 & 6 & 12-Jan-10 & 9139 & 0,6036 & 0,4317 & $-0,9210$ & 5 & $-0,000213007$ & $2,31726 \mathrm{E}-11$ & & & \\
\hline 20 & 7 & 13-Jan-10 & 9134 & $-0,0547$ & 0,4218 & $-0,4909$ & 6 & 0,006924456 & $2,45008 \mathrm{E}-08$ & & & \\
\hline 21 & 8 & 14-Jan-10 & 9104 & $-0,3290$ & 0,3404 & $-0,5391$ & 7 & $-0,001470868$ & $1,10606 \mathrm{E}-09$ & & & \\
\hline 22 & 9 & 15-Jan-10 & 9159 & 0,6023 & 0,2973 & $-0,9226$ & 8 & 0,020933029 & $2,24139 \mathrm{E}-07$ & & & \\
\hline 23 & 10 & 18-Jan-10 & 9184 & 0,2726 & 0,3149 & $-0,4592$ & 9 & 0,025405963 & $3,30329 \mathrm{E}-07$ & & & \\
\hline 24 & 11 & 19-Jan-10 & 9179 & $-0,0545$ & 0,2702 & $-0,2701$ & 10 & 0,004017265 & $8,2634 \mathrm{E}-09$ & & & \\
\hline
\end{tabular}

Gambar 6. Implementasi MS Excel untuk GARCH(1,1) mengadopsi data returns kurs beli USD terhadap IDR periode 2010-2017.

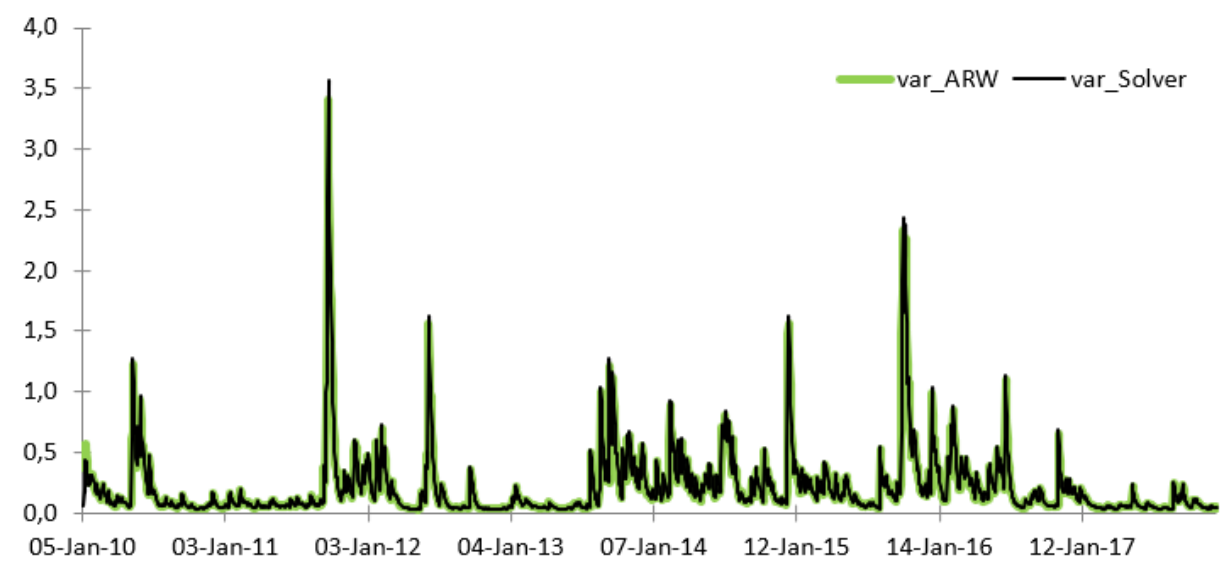

GAMBAR 7. Plot runtun waktu variansi untuk returns kurs beli USD terhadap IDR periode 2010-2017.

\section{Daftar Pustaka}

[1] Abdalla, S. Z. S., and Winker, P., 2012, Modelling stock market volatility using univariate GARCH models: Evidence from Sudan and Egypt, International Journal of Economics and Finance Volume 4, Issue 8, pp 161-176. DOI: https://doi.org/10.5539/ijef.v4n8p161

[2] Adanu, K., 2006, Optimizing the GARCH model-An application of two global and two local search methods, Computational Economics, Volume 28, Issue 3, pp 277-290. DOI: https://doi.org/10.1007/ s10614-006-9048-0

[3] Alberg, D., Shalit, H., and Yosef, R., 2008, Estimating stock market volatility using asymmetric GARCH models, Applied Financial Economics, Volume 18, Issue 15, pp 1201-1208. DOI: https://doi.org/10. $1080 / 09603100701604225$

[4] Alexander, C., 2008, Market Risk Analysis II: Practical Financial Econometrics, John Wiley \& Sons, Chichester.

[5] Bollerslev, T., 1986, Generalized autoregressive conditional heteroskedasticity, Journal of Econometrics, Volume 31, Issue 3, pp 307-327. DOI: https://doi.org/10.1016/0304-4076(86)90063-1

[6] Brewer, K. D., Feng, Y., and Kwan, C. C. Y., 2012, Geometric Brownian motion, option pricing, and simulation: Some spreadsheet-based exercises in financial modeling, Spreadsheets in Education, Volume 5, Issue 3. Retrieved from http://epublications.bond.edu.au/ejsie/vol5/iss3/4 
[7] Brown, R., and Klingenberg, B., 2015, Real estate risk: Heavy tail modelling using Excel. Journal of Property Investment \& Finance, Volume 33, Issue 4, pp 393-407. DOI: https://doi.org/10.1108/ JPIF-0b-2014-0033

[8] Christoffersen, P. F., 2012, Elements of Financial Risk Management (2nd ed.), Academic Press, New York.

[9] Epaphra, M., 2017, Modeling exchange rate volatility: Application of the GARCH and EGARCH models, Journal of Mathematical Finance, Volume 7, Issue 1, pp 121-143. DOI: https://doi.org/10.4236/jmf. $201 \% .11000$

[10] Fan, J., Qi, L., and Xiu, D., 2014, Quasi-maximum likelihood estimation of GARCH models with heavytailed likelihoods, Journal of Business and Economic Statistics, Volume 32, Issue 2, pp 178-191. DOI: https://doi.org/10.1080/07350015.2013.840239

[11] Francq, C., Lepage, G., and Zakoian, J.-M., 2011, Two-stage non Gaussian QML estimation of GARCH models and testing the efficiency of the Gaussian QMLE, Journal of Econometrics, Volume 165, pp 246257. DOI: https://doi.org/10.1016/j.jeconom.2011.08.001

[12] Francq, C., and Zakoian, J.-M., 2004, Maximum likelihood estimation of pure GARCH and ARMA-GARCH processes, Bernoulli, Volume 10, pp 605-637. DOI

[13] French, N., 2006, Value and worth: probability analysis, Journal of Property Investment E Finance, Volume 24, Issue 4, pp 374-380.DOI: https://doi.org/10.1108/14635780610674543

[14] French, N., 2015, Spreadsheets for valuations 50 worked examples using Microsoft Excel 2010, Journal of Property Investment $\& 3$ Finance, Volume 33, Issue 2, pp 205-206. DOI: https://doi.org/10.1108/ JPIF-12-2014-00/4

[15] Giot, P., and Laurent, S., 2004, Modelling daily Value-at-Risk using realized volatility and ARCH type models, Journal of Empirical Finance, Volume 11, Issue 3, pp 379-398. DOI: https://doi.org/10.1016/ j.jemptin.2003.04.003

[16] Hansen, P. R., and Lunde, A., 2005, A forecast comparison of volatility models: Does anything beat a GARCH(1,1)? Journal of Applied Econometrics, Volume 20, Issue 7, pp 873-889. DOI: https://doi.org/ $10.1002 / \mathrm{jae} .800$

[17] Harmon, M., 2011, Step-by-step optimization with Excel Solver, Excel Master Series.

[18] Huang, D., Wang, H., and Yao, Q., 2008, Estimating GARCH models: When to use what? Econometrics Journal, Volume 11, Issue 1, pp 27-38. DOI: https://doi.org/10.1111/j.1368-423X.2008.00229.x

[19] Kamal, Y. H., Ghani, U., and Khan, M. M., 2012, Modeling the exchange rate volatility, using generalized autoregressive conditionally heteroscedastic $(\mathrm{GARCH})$ type models: Evidence from Pakistan, African Journal of Business Management, Volume 6, Issue 8, pp 2830-2838. DOI: https://doi.org/10.5897/ A.TBM10. 165 (

[20] Kuka, S., and Karamani, B., 2011, Using Excel and VBA for Excel to learn numerical methods. In The 1st International Sympsosium on Computing in Informatics and Mathematics (pp. 365-376). Retrieved from https://fac.ksu.edu.sa/sites/default/files/739-2470-1-pb.pdf

[21] Kyng, T. J., 2016, Excel implementation of finite difference methods for option pricing, Spreadsheets in Education, Volume 9, Issue 3. Retrieved from http://epublications.bond.edu.au/ejsie/vol9/iss3/2/

[22] Kyng, T. J., and Konstandatos, O., 2014, Multivariate Monte-Carlo simulation and economic valuation of complex financial contracts: An excel based implementation. Spreadsheets in Education, Volume 7, Issue 2. Retrieved from http://epublications.bond.edu.au/ejsie/vol7/iss2/5/

[23] Lawrence, K. D., Klimberg, R. K., and Lawrence, S. M., 2009, Fundamentals of Forecasting Using Excel, Industrial Press, New York.

[24] Levy, G., 2004, Computational Finance: Numerical Methods for Princing Financial Instruments, Elsevier, Oxford.

[25] Nadler, S., and Kros, J. F., 2007, Forecasting with Excel: Suggestions for managers, Spreadsheets in Education, Volume 2, Issue 2. Retrieved from http://epublications.bond.edu.au/cgi/viewcontent.cgi?article=1038\&context=ejsie

[26] Nugroho, D. B., 2018, Comparative analysis of three MCMC methods for estimating GARCH models. In IOP Conference Series: Materiasl Science and Engineering (Vol. 403, Number 1, 012061). DOI: https: //doi.org/10.1088/1757-899X/403/1/012061

[27] Nugroho, D. B., and Susanto, B., 2017, Volatility modeling for IDR exchange rate through APARCH model with student-t distribution. In AIP Conference Proceedings (Vol. 1868, p. 040005-1-040005-8), AIP Publishing LLC. DOI: https://doi.org/10.1063/1.4995120

[28] Nugroho, D. B., Susanto, B., and Pratama, S. R., 2017, Estimation of exchange rate volatility using APARCH-type models: A case study of Indonesia (2010-2015), Jurnal Ekonomi dan Studi Pembangunan, Volume 9, Issue 1, pp 65-75. DOI: http://dx.doi.org/10.17977/um002v9i12017p065

[29] Poon, S.-H., and Granger, C. W. J., 2003, Forecasting volatility in financial markets: A review, Journal of Economic Literature, Volume 41, Issue 2, pp 478-539. DOI: https://doi.org/10.1257/ $002) 05103765 / 62743$

[30] Posedel, P., 2005, Properties and estimation of GARCH(1,1) model, Metodoloki Zvezki, Volume 2, Issue 2, pp 243-257. 
[31] Racicot, F. E., and Theoret, R., 2007, Option pricing models \& volatility using Excel-VBA (by F. D. Rouah and G. Vainberg), Journal of Derivatives \& Hedge Funds, Volume 13, Issue 2, pp 181-183. DOI: https://doi.org/10.1057/palgrave.jdhf.1850068

[32] Rouah, F. D., and Vainberg, G., 2007, Option Pricing Models and Volatility Using Excel-VBA, John Wiley \& Sons, Hoboken.

[33] Ruppert, D., 2011, Statistics and Data Analysis for Financial Engineering, Springer, New York.

[34] Salim, F. C., Nugroho, D. B., and Susanto, B., 2016, Model volatilitas GARCH(1,1) dengan error Student-t untuk kurs beli EUR dan JPY terhadap IDR, Jurnal MIPA, Volume 39, Issue 1, pp 63-69.

[35] Thadewald, T., and Buning, H., 2007, Jarque-Bera test and its competitors for testing normality - A power comparison, Journal of Applied Statistics, Volume 34, Issue 1, pp 87-105. DOI: https://doi.org/10.1080/ 026647606009.9453 .39

[36] Tung, H. K. K., Lai, D. C. F., and Wong, Mi. C. S., 2010, Professional Financial Computing Using Excel and $V B A$. John Wiley \& Sons, Singapore.

[37] Williams, N., 2001, Excel for surveyors, Journal of Property Investment \& Finance, Volume 19, Issue 3, pp 330-331. DOI: https://doi.org/10.1108/jpif.2001.19.3.330.1

[38] Winston, W. L., 1998, @RISK: Advanced risk analysis for spreadsheets simulating modeling using @Risk, Journal of Property Valuation and Investment, Volume 16, Issue 3, pp 344-345. DOI: https://doi.org/ 10.1108/jpvi.1998.16.3.344.2 
